\title{
ALGORITMA POLINOMIAL MINIMUM UNTUK MEMBENTUK MATRIKS DIAGONAL DARI MATRIKS PERSEGI
}

\author{
Himmatul Mursyidah \\ Universitas Muhammadiyah Surabaya \\ E-mail: himmatul.pendmat@fkip.um-surabaya.ac.id
}

\begin{abstract}
In mathematics, matrices have many uses, they are finding solutions of a linear equation system, looking for specific solutions of differential equations, determining state classification on Markov chains, and so on. There is a special matrix in matrix theory, that is a diagonal matrix. The diagonal matrix is a matrix whose all nondiagonal entries are primarily zero so that the product of the diagonal matrix can be computed by considering only the components along the main diagonal. A square matrix can sometimes be formed into a diagonal matrix. If a non-diagonal square matrix $A$ can be conjugated with a diagonal matrix, then there is an invertible matrix $P$ so $P A P^{-1}=D$, where $D$ is a diagonal matrix and $P$ is said to diagonalize A. To find a square matrix diagonalizable or not, many researchers usually use eigenvalues and eigenvectors evaluation. In this study, we discuss that the other way to form a diagonal matrix by using Minimum Polynomial Algorithm.
\end{abstract}

Keywords: diagonal matrix, matrices, minimum polynomial

\section{PENDAHULUAN}

Teori matriks dan aplikasinya telah mengalami perkembangan yang sangat luas. Perkembangan teori matriks terjadi baik dalam matematika sendiri maupun dalam aplikasi yang digunakan untuk mengembangkan ilmu-ilmu lain. Terdapat banyak kegunaan matriks dalam matematika, khususnya yang berkaitan dengan aplikasi aljabar linear. Solusi dari suatu sistem persamaan linear dapat dicari dengan menggunakan matriks. Pada persamaan differensial, solusi partikulir atau penyelesaian khusus dapat dicari dengan metode matriks. Sedangkan matriks peluang transisi digunakan untuk menentukan klasifikasi state pada rantai markov (Langi, 2011).

Terdapat bentuk matriks yang memiliki keistimewaan dalam teori matriks, yaitu matriks diagonal. Keistimewaan dari matriks diagonal terletak pada operasi aljabarnya.
Matriks diagonal merupakan matriks persegi dengan seluruh entri nondiagonal utamanya sama dengan nol (Lipschutz \& Lipson, 2009). Operasi aljabar maupun produk dari matriks diagonal dapat dihitung dengan hanya memperhatikan komponen sepanjang diagonal utamanya, sehingga kerumitan dari operasi aljabar matriks berkurang ketika bekerja dengan matriks diagonal.

Adakalanya suatu matriks yang tidak berbentuk diagonal dapat dibentuk menjadi matriks diagonal. Jika suatu matriks persegi $A$ tidak berbentuk diagonal tetapi dapat dikonjugasikan dengan matriks diagonal, maka terdapat matriks invertible $P$ sehingga $P A P^{-1}=$ $D$, dengan $D$ adalah matriks diagonal dan $P$ dikatakan mendiagonalisasi $A$ (Anton \& Rorres, 2005). Ada juga matriks yang tidak dapat dibentuk kembali menjadi matriks diagonal. Matriks tersebut cukup dapat dibentuk 
menjadi matriks yang similar dengan matriks yang hampir diagonal.

Untuk mengetahui suatu matriks persegi dapat didiagonalisasi atau tidak, banyak peneliti menggunakan pengevaluasian terhadap nilai eigen dan vektor eigen matriks selama ini. Dimensi dari ruang eigen yang menunjukkan jumlah vektor-vektor eigen yang bersesuaian dengan suatu nilai eigen dinamakan multiplisitas geometri. Sedangkan jumlah nilai eigen yang sama (kembar) dinamakan multiplisitas aljabar. Suatu matriks dapat didiagonalisasi apabila multiplisitas geometri sama dengan mltiplisitas aljabar.

Dalam penelitian ini, dibahas bahwa untuk mendeteksi suatu matrik persegi juga dapat digunakan suatu polinomial khusus, yaitu polinomial minimum. Diketahui bahwa untuk mendapatkan vektor-vektor eigen dari suatu matriks bukan hal yang mudah. Dengan menggunakan polinomial minimum, maka tidak harus mencari vektor-vektor eigen yang bersesuaian dengan masing-masing nilai eigen suatu matriks terlebih dahulu. Lebih lanjut, dalam penelitian ini disusun pula suatu algoritma untuk membentuk matriks diagonal dari matriks persegi dengan menggunakan polinomial minimum.

\section{POLINOMIAL DAN MATRIKS}

Polinomial merupakan pernyataan matematika yang memuat jumlahan dari satu atau lebih varibel berpangkat dengan koefisien. Berdasarkan pernyataan tersebut, polinomial dapat dibagi menjadi polinomial dengan satu variabel dan polinomial lebih dari satu variabel. Untuk polinomial dengan satu variabel, pangkat tertinggi dari variabel menunjukkan orde atau derajat polinomial. Definisi polinomial satu variabel dapat ditulis,
Definisi 1. Sebuah polinomial atas $\mathbb{F}$ adalah jumlahan $a_{0}+\cdots+a_{n} x^{n}$ dengan $a_{i} \in \mathbb{F}$ merupakan koefisien dari polinomial tersebut untuk $i=0, \ldots, n$, dan $n$ adalah derajat polinomial (deg).

Berdasarkan derajatnya, polinomial satu variabel terdiri dari beberapa jenis. Berikut diberikan penjelasan dan bentuk dari beberapa jenis polinomial satu varibel.

1. Polinomial konstanta tak nol, yaitu polinomial berderajat 0 dengan koefisien tidak sama dengan nol. Bentuk dari polinomial konstanta tak nol adalah $P(x)=a$, dengan $a$ anggota dari suatu lapangan.

2. Polinomial nol, merupakan polinomial berderajat 0 dengan koefisien sama dengan nol. Bentuk polinomial nol yaitu $P(x)=0$.

3. Polinomial linear, yaitu polinomial berderajat 1 yang mempunyai bentuk $P(x)=a x+b, \quad$ dengan $a \neq 0$ dan $b$ anggota dari suatu lapangan.

4. Polinomial kuadratik, merupakan polinomial berderajat 2. Bentuk polinomial kuadratik yaitu $P(x)=$ $a x^{2}+b x+c$, dengan $a \neq 0, b$, dan $c$ anggota dari suatu lapangan.

5. Polinomial kubik, merupakan polinomial berderajat 3 . Bentuk polinomial kubik yaitu $P(x)=$ $a x^{3}+b x^{2}+c x+d$, dengan $a \neq$ $0, b, c$, dan $d$ anggota dari suatu lapangan,

dan masih banyak jenis polinomial satu variabel berdasarkan derajatnya. Himpunan dari polinomial-polinomial satu variabel (misal $x$ ) atas suatu lapangan $\mathbb{F}$ dinotasikan dengan $\mathbb{F}[x]$.

Terdapat jenis khusus polinomial satu variabel berdasarkan koefisien dari variabel dengan pangkat tertingginya. Polinomial tersebut dinamakan polinomial monik. 
Definisi 2. Polinomial monik adalah suatu polinomial dengan koefisien utamanya atau koefisien dari variabel yang memiliki pangkat tertinggi sama dengan 1 (Riyanto, 2008).

Untuk memperjelas definisi dari polinomial monik, berikut diberikan contoh dari polinomial monik dan tidak.

Contoh 3. Polinomial $x^{2}-5 x+6$ merupakan polinomial monik berderajat dua. Sedangkan $2 x^{3}+7 x^{2}+2 x-3$ adalah polinomial berderajat tiga yang bukan monik.

Polinomial ada yang dapat direduksi dan ada yang tidak. Polinomial yang dapat direduksi adalah polinomial yang dapat dinyatakan sebagai perkalian antara dua polinomial berderajat positif. Sedangkan pengertian dari polinomial tak tereduksi, diberikan pada definisi berikut,

Definisi 4. Polinomial $f(x) \in \mathbb{F}[x]$ disebut tak tereduksi jika $f(x)$ berderajat positif dan $f(x)$ tidak dapat dinyatakan sebagai perkalian antara dua polinomial berderajat positif. Dengan kata lain, jika $f(x)=h(x) g(x)$ maka $h(x)$ konstan atau $g(x)$ konstan (Riyanto, 2008).

Pada contoh berikut, diberikan polinomial tak tereduksi sekaligus tereduksi. Hal tersebut tergantung pada lapangan dari koefisien maupun konstanta polinomial.

Contoh 5. Polinomial $x^{2}+1$ merupakan polinomial tak tereduksi di $\mathbb{R}[x]$ sebab polinomial tersebut tidak dapat dinyatakan sebagai perkalian dua polinomial berderajat positif anggota dari $\mathbb{R}[x]$. Akan tetapi, polinomial $x^{2}+1$ merupakan polinomial tereduksi di $\mathbb{C}[x]$ sebab terdapat $x+i, x-i \in$
$\mathbb{C}[x]$ dengan $i=\sqrt{-1}$ sedemikian hingga $x^{2}+1=(x+i)(x-i)$.

Operasi aljabar seperti penjumlahan dan pengurangan, perkalian, maupun pembagian juga berlaku pada polinomial. Dalam operasi pembagian polinomial, dikenal teorema pembagian yang mengulas mengenai hasil bagi dan sisa hasil bagi.

Teorema 6. Diberikan $\mathbb{F}$ suatu lapangan, dan polinomial $f(x), h(x) \in$ $\mathbb{F}[x]$ dengan $h(x) \neq 0$, maka terdapat dengan tunggal $q(x), r(x) \in \mathbb{F}[x]$ sedemikian hingga

$$
f(x)=q(x) h(x)+r(x)
$$

dengan $\quad r(x)=0$ atau $\operatorname{deg} r(x)<$ $\operatorname{deg} h(x)$.

Setelah diberikan uraian mengenai polinomial, jenis, dan operasinya yang digunakan dalam proses penelitian. Selanjutnya, diberikan penjelan tentang matriks dan beberapa jenis matriks khusus. Matriks merupakan susunan bilangan berbentuk persegi panjang, dengan bilangan-bilangan dalam susunan tersebut atas suatu lapangan tertentu. Bilangan yang menyusun suatu matriks disebut sebagai entri dari matriks. Ukuran dari suatu matriks ditentukan dari jumlah baris dan kolomnya.

Definisi 7. Sebuah matriks berukuran $m \times n$ adalah himpunan beberapa bilangan yang tersusun dalam persegi panjang berukuran $m$ baris dan $n$ kolom yang dapat ditulis sebagai

(Eves, 1968).

$$
A=\left[\begin{array}{cccc}
a_{11} & a_{12} & \ldots & a_{1 n} \\
a_{21} & a_{22} & \ldots & a_{2 n} \\
\vdots & \vdots & \ddots & \vdots \\
a_{m 1} & a_{m 2} & \ldots & a_{m n}
\end{array}\right]
$$

Dalam teori matriks, terdapat beberapa jenis matriks khusus yang 
memiliki keistimewaan. Jenis-jenis matriks khusus tersebut, yaitu matriks nol, vektor baris, vektor kolom, matriks persegi, matriks diagonal, matriks identitas, dan matriks segitiga atas/bawah. Keistimewaan dari matrikmatriks khusus tersebut diantaranya dalam hal nilai-nilai entri matriks, operasi aljabar, perhitungan komponenkomponen dari matriks, dan sebagainya. Berikut dibahas satu persatu jenis-jenis matriks khusus.

Suatu matriks dengan seluruh entri sama dengan nol disebut matriks nol, dan dinotasikan dengan $O$. Dilihat dari ukurannya, matriks berukuran $1 \times n$ yaitu matriks yang terdiri dari 1 baris dan $n$ kolom disebut vektor baris. Sedangkan matriks dengan ukuran $m \times 1$ yaitu matriks yang terdiri dari $m$ baris dan 1 kolom disebut vektor kolom.

Contoh 8. Matriks $O_{3 \times 2}=\left[\begin{array}{ll}0 & 0 \\ 0 & 0 \\ 0 & 0\end{array}\right]$ adalah contoh matriks nol berukuran $3 \times 2$. Adapun $\left[\begin{array}{lll}-2 & 0 & 3\end{array}\right]$ merupakan vektor baris dan $\left[\begin{array}{l}2 \\ 3 \\ 0\end{array}\right]$ merupakan vektor kolom.

Suatu matriks yang mempunyai ukuran baris sama dengan ukuran kolom disebut matriks persegi. Misalkan suatu matriks persegi terdiri dari $n$ baris dan $n$ kolom, maka dapat diartikan bahwa matriks tersebut memiliki order $n$. Secara umum bentuk matriks persegi $A_{n \times n}$ adalah

$$
\left[\begin{array}{cccc}
a_{11} & a_{12} & \ldots & a_{1 n} \\
a_{21} & a_{22} & \ldots & a_{2 n} \\
\vdots & \vdots & \ddots & \vdots \\
a_{n 1} & a_{n 2} & \ldots & a_{n n}
\end{array}\right]
$$

dengan $a_{11}, a_{22}, \ldots, a_{n n}$ merupakan diagonal utama dari matriks $A_{n \times n}$. Matriks persegi dengan entri nondiagonal utamanya sama dengan nol disebut matriks diagonal. Lebih lanjut, matriks diagonal dengan seluruh entri diagonal utamanya sama dengan 1 disebut matriks identitas. Matriks identitas dinotasikan dengan $I$.

Contoh 9. Matriks $\quad B=\left[\begin{array}{lll}1 & 0 & 0 \\ 0 & 0 & 0 \\ 0 & 0 & 1\end{array}\right]$ adalah contoh matriks persegi berorder 3 , sekaligus matriks diagonal. Sedangkan matriks $I=\left[\begin{array}{ccc}1 & 0 & 0 \\ 0 & 1 & 0 \\ 0 & 0 & 1\end{array}\right]$ merupakan matriks identitas berukuran $3 \times 3$.

Suatu matriks persegi yang semua entri di bawah diagonal utamanya sama dengan nol disebut sebagai matriks segitiga atas. Sedangkan matriks persegi yang semua entri di atas diagonal utamanya sama dengan nol disebut matriks segitiga bawah. Untuk memperjelas pengertian tersebut, diberikan masing-masing contoh matriks segitiga atas dan bawah.

Contoh 10. Matriks $A=\left[\begin{array}{ll}2 & 1 \\ 0 & 2\end{array}\right]$ dan $U=\left[\begin{array}{lll}0 & 2 & 3 \\ 0 & 0 & 6 \\ 0 & 0 & 0\end{array}\right]$ merupakan contoh matriks segitiga atas. Sedangkan matriks $\quad B=\left[\begin{array}{cc}0 & 0 \\ -1 & 2\end{array}\right]$ dan $L=$ $\left[\begin{array}{ccc}2 & 0 & 0 \\ -1 & 7 & 0 \\ 3 & 4 & 5\end{array}\right]$ adalah contoh matriks segitiga bawah.

Setiap matriks persegi mempunyai determinan. Determinan merupakan pemetaan dengan domain matriks persegi dan kodomain berupa suatu nilai skalar. Misal diberikan matriks $A$, determinan dari matriks dinotasikan dengan $|A|$ atau $\operatorname{det} A$. Untuk mendapatkan determinan dari suatu matriks, dapat digunakan aturan sarrus (hanya untuk matriks berorder 2 dan 3) 
maupun metode minor-kofaktor. Determinan suatu matriks dapat digunakan untuk menganalisa suatu matriks, salah satunya yaitu untuk memeriksa keberadaan invers dari matriks tersebut.

Definisi 11. Suatu matriks persegi $A$ berorder $n$ dikatakan invertible jika terdapat suatu matriks $A^{-1}$ sedemikian hingga $A A^{-1}=A^{-1} A=I$ dengan $I$ merupakan matriks identitas berukuran $n \times n$, dan $A^{-1}$ adalah invers dari matriks $A$ (Koryanov, 2015).

Suatu matriks persegi mempunyai invers jika dan hanya jika determinan dari matriks tersebut tidak sama dengan nol. Untuk memperjelas penjelasan tersebut, diberikan contoh perhitungan invers matriks menggunakan determinan.

Contoh 12. Diberikan matriks $A=$ $\left[\begin{array}{ll}4 & 3 \\ 2 & 1\end{array}\right]$. Determinan dari $A$ sama dengan -2 dan adjoint $A$ sama dengan $\left[\begin{array}{cc}1 & -3 \\ -2 & 4\end{array}\right]$, sehingga untuk menghitung invers dari matriks tersebut digunakan rumus:

$$
\begin{aligned}
A^{-1}= & \frac{1}{\operatorname{det} A} \text { Adjoint } A \\
& =\frac{1}{-2}\left[\begin{array}{cc}
1 & -3 \\
-2 & 4
\end{array}\right] \\
& =\left[\begin{array}{cc}
-\frac{1}{2} & \frac{3}{2} \\
1 & -2
\end{array}\right]
\end{aligned}
$$

Diperoleh invers dari matriks $A$ sama dengan $\left[\begin{array}{cc}-1 / 2 & 3 / 2 \\ 1 & -2\end{array}\right]$. Jadi apabila determinan suatu matriks bernilai nol, maka terdapat pembagian 1 dengan 0 sehingga invers dari matriks tersebut tidak terdefinisi.

Dalam pembahasan mengenai matriks persegi, terdapat dua hal yang perlu dipahami yaitu nilai eigen dan vektor eigen. Nilai eigen adalah nilai karakteristik dari suatu matriks persegi, nilai eigen dinotasikan dengan $\lambda$. Sedangkan vektor eigen adalah vektor kolom bukan nol yang apabila dikalikan dengan suatu matriks persegi beroder $n$ akan menghasilkan vektor lain yang mempunyai kelipatan dari vektor eigen tersebut.

Definisi 13. Diberikan matriks persegi $A$ berukuran $n \times n$ dengan entri di suatu lapangan $\mathbb{F}$. Jika ada vektor tak nol $\mathbf{x} \in \mathbb{F}^{n} \quad$ dan skalar $\quad \lambda \in \mathbb{F}$ yang memenuhi $A \mathbf{x}=\lambda \mathbf{x}$, maka $\mathbf{x}$ disebut sebagai vektor eigen dari matriks $A$ yang bersesuaian dengan nilai eigen $\lambda$ (Subiono, 2012).

Kumpulan pasangan nilai dan vektor eigen dari suatu matriks persegi disebut sistem eigen dari matriks tersebut. Sedangkan kumpulan dari vektor eigen yang bersesuaian dengan suatu nilai eigen $\lambda$ digabungkan dengan vektor nol disebut ruang eigen dari $\lambda$, dan dapat dinotasikan dengan $E_{\lambda}$. Tidak semua matriks mempunyai nilai eigen dan vektor eigen. Hal tersebut tergantung pada lapangan dari entri matriks.

Contoh 14. Diberikan matriks $A=$ $\left[\begin{array}{ll}2 & 1 \\ 1 & 2\end{array}\right]$ atas lapangan real $\mathbb{R}$. Nilai eigen dari matriks $A$ dapat dihitung melalui formula berikut:

$$
\operatorname{det}(A-\lambda I)=0
$$

diperoleh nilai eigen dari matriks $A$ yaitu $\lambda_{1}=1$ dan $\lambda_{2}=3$. Selanjutnya, vektor eigen yang bersesuaian dengan nilai-nilai eigen dari matriks $A$ diperoleh dengan menggunakan formula:

$$
(A-\lambda I) \mathbf{x}=0
$$

Sehingga didapat vektor eigen yang bersesuaian dengan $\lambda_{1}=1$ adalah $\mathbf{x}_{\mathbf{1}}=a\left[\begin{array}{c}-1 \\ 1\end{array}\right]$ dengan $a \in \mathbb{R}$, dan vektor 
eigen yang bersesuaian dengan $\lambda_{2}=3$ adalah $\quad \mathbf{x}_{2}=b\left[\begin{array}{l}1 \\ 1\end{array}\right] \quad$ dengan $\quad b \in \mathbb{R}$. Berdasarkan uraian tersebut diketahui bahwa matriks $A$ atas lapangan $\mathbb{R}$ mempunyai nilai eigen dan vektor eigen. Adapun untuk matriks $B=$ $\left[\begin{array}{cc}0 & 1 \\ -1 & 0\end{array}\right]$ atas lapangan real $\mathbb{R}$ tidak mempunyai nilai eigen sebab dengan menggunakan formula untuk menghitung nilai eigen, didapatkan nilai eigen dari matriks $B$ yaitu $\lambda_{1}=-i$ dan $\lambda_{2}=i$ dengan $i=\sqrt{-1}$ merupakan elemen bilangan kompleks. Hal tersebut berakibat matriks tersebut juga tidak mempunyai vektor eigen. Lebih lanjut, matriks $B$ atas lapangan kompleks $\mathbb{C}$ mempunyai nilai eigen, yaitu $\lambda_{1}=-i$ dan $\lambda_{2}=i$. Vektor eigen yang bersesuaian dengan $\lambda_{1}=-i$ adalah $\mathbf{x}_{\mathbf{1}}=a\left[\begin{array}{c}1 \\ -i\end{array}\right]$ dengan $a \in \mathbb{C}$, dan vektor eigen yang yang bersesuaian dengan $\lambda_{2}=i$ adalah $\mathbf{x}_{2}=b\left[\begin{array}{l}1 \\ i\end{array}\right]$ dengan $b \in$ C.

Misal $\lambda_{1}$ adalah suatu nilai eigen dari suatu matriks $A$. Multiplisitas aljabar dari $\lambda_{1}$ adalah banyaknya $\lambda_{1}$ sebagai akar dari persamaan polinomial $A$. Sedangkan multiplisitas geometri $\lambda_{1}$ adalah dimensi ruang eigen yang bersesuaian dengan nilai eigen $\lambda_{1}$ (Anton \& Rorres, 2005). Multiplisitas geometri masing-masing nilai eigen dari suatu matriks kurang dari atau sama dengan multiplisitas aljabarnya.

Contoh 15. Diberikan matriks $A=$ $\left[\begin{array}{ll}2 & 1 \\ 1 & 2\end{array}\right]$ seperti pada Contoh 14. Berdasarkan pembahasan pada Contoh 14 diperoleh nilai eigen dari matriks $A$ adalah $\lambda_{1}=1$ dan $\lambda_{2}=3$, dengan ruang eigen yang bersesuaian dengan $\lambda_{1}=1$ adalah $\left\langle\left[\begin{array}{c}-1 \\ 1\end{array}\right]\right\rangle$ dan ruang eigen yang bersesuaian dengan $\lambda_{2}=3$ adalah $\left\langle\left[\begin{array}{l}1 \\ 1\end{array}\right]\right\rangle$. Berdasarkan hasil perhitungan nilai eigen dan vektor eigen dari matriks $A$ tersebut diperoleh multiplisitas aljabar dari $\lambda_{1}$ sama dengan 1 sebab nilai eigen dari matriks $A$ yang sama dengan 1 sejumlah satu, sedangkan multiplisitas geometri $\lambda_{1}$ sama dengan 1 sebab dimensi ruang eigen dari $\lambda_{1}$ sama dengan 1. Adapun multiplisitas aljabar dari $\lambda_{2}$ sama dengan 1 dan multiplisitas geometri $\lambda_{2}$ juga sama dengan 1 .

Contoh 16. Misal diberikan matriks $C=\left[\begin{array}{ll}1 & 2 \\ 0 & 1\end{array}\right]$ atas lapangan $\mathbb{R}$. Nilai eigen dari matriks $C$ adalah $\lambda_{1}=\lambda_{2}=$ 1 dengan vektor eigen yang bersesuaian dengan $\lambda_{1}$ dan $\lambda_{2}$ adalah $a\left[\begin{array}{l}1 \\ 0\end{array}\right], a \in \mathbb{R}$, sedemikian hingga $E_{\lambda_{1}}=E_{\lambda_{2}}=\left\langle\left[\begin{array}{l}1 \\ 0\end{array}\right]\right\rangle$. Dari uraian tersebut didapatkan bahwa matriks $C$ mempunyai dua nilai eigen dan keduanya bernilai sama yaitu 1 sehingga multiplisitas aljabar dari nilai eigen tersebut sama dengan 2 . Sedangkan multiplisitas geometri dari $\lambda_{1}$ maupun $\lambda_{2}$ sama dengan 1 sebab dimensi ruang eigen dari $\lambda_{1}$ maupun $\lambda_{2}$ masing-masing sama dengan 1 .

\section{METODE PENELITIAN}

Penelitian ini merupakan penelitian studi literatur. Metode yang digunakan adalah dengan mengumpulkan bahan penelitian dari buku-buku, jurnal, maupun dokumen dari website yang membahas mengenai polinomial dan salah satu jenisnya yaitu polinomial minimum, matriks khusus yaitu matriks diagonal, serta cara untuk mendiagonalisasi matriks persegi menjadi matriks diagonal yang selama ini umum digunakan. Selanjutnya, dari 
literatur-literatur yang diperoleh dilakukan kajian terhadap konsepkonsep tersebut untuk mengkontruksi suatu algoritma polinomial minimum sebagai cara lain untuk membentuk matriks diagonal dari suatu matriks persegi.

\section{ALGORITMA POLINOMIAL MINIMUM UNTUK MENDIAGONALISASI MATRIKS PERSEGI}

Suatu matriks persegi adakalanya dapat dijadikan bentuk matriks diagonal. Cara yang biasa digunakan untuk memeriksa suatu matriks dapat didiagonalkan adalah dengan menggunakan multiplisitas aljabar dan multiplisitas geometri.

Teorema 17. Misal $A$ adalah matriks persegi. Matriks $A$ dapat didiagonalisasi jika dan hanya jika untuk setiap nilai eigen dari $A$ multiplisitas geometri sama dengan multiplisitas aljabarnya (Lipschutz \& Lipson, 2009).

Berdasarkan Contoh 15, matriks $A=\left[\begin{array}{ll}2 & 1 \\ 1 & 2\end{array}\right]$ mempunyai dua buah nilai eigen yaitu $\lambda_{1}=1$ dan $\lambda_{2}=3$, dengan multiplisitas geometri $\lambda_{1}$ sama dengan multiplisitas aljabarnya yaitu 1 . Begitu pula untuk nilai eigen $\lambda_{2}$, multiplisitas geometri juga sama dengan multiplisitas aljabarnya yaitu 1. Dengan menggunakan Teorema 17, dapat disimpulkan bahwa matriks $A$ merupakan matriks yang dapat didiagonalkan. Adapun matriks $C=\left[\begin{array}{ll}1 & 2 \\ 0 & 1\end{array}\right]$ yang mempunyai dua buah nilai eigen $\lambda_{1}=\lambda_{2}=1$ pada Contoh 16 merupakan matriks yang tidak dapat didiagonalkan sebab multiplisitas geometri dari nilai eigen kurang dari multiplisitas aljabarnya.

Pada bagian pendahuluan telah dijelaskan bahwa suatu matriks persegi $A$ yang tidak berbentuk diagonal tetapi dapat dikonjugasikan dengan matriks diagonal, jika terdapat matriks invertible $P$ sehingga $P A P^{-1}=D$, dengan $D$ adalah matriks diagonal dan $P$ dikatakan mendiagonalisasi $A$. Sehingga untuk dapat membentuk matriks diagonal $D$ dari matriks persegi yang sudah diidentifikasi dapat didiagonalkan adalah dengan menyusun matriks invertible $P$ kemudian digunakan rumus:

$$
D=P A P^{-1}
$$

Contoh 18. Pada pembahasan sebelumnya, didapatkan bahwa matriks $A=\left[\begin{array}{ll}2 & 1 \\ 1 & 2\end{array}\right]$ merupakan matriks yang dapat didiagonalkan. Untuk mendapatkan bentuk diagonal dari matriks $A$ terlebih dahulu disusun matriks invertible $P=\left[\begin{array}{llll}\mathbf{x}_{1} & \mathbf{x}_{2} & \ldots & \mathbf{x}_{\mathbf{n}}\end{array}\right]$, yaitu:

$\begin{aligned} P & =\left[\begin{array}{cc}-1 & 1 \\ 1 & 1\end{array}\right] \\ \text { dengan } \quad P^{-1} & =\left[\begin{array}{cc}-\frac{1}{2} & \frac{1}{2} \\ \frac{1}{2} & \frac{1}{2}\end{array}\right], \quad \text { sedemikian }\end{aligned}$ hingga diperoleh bentuk diagonal dari matriks $A$ adalah

$$
\begin{aligned}
D & =P A P^{-1} \\
& =\left[\begin{array}{cc}
-1 & 1 \\
1 & 1
\end{array}\right]\left[\begin{array}{ll}
2 & 1 \\
1 & 2
\end{array}\right]\left[\begin{array}{cc}
-\frac{1}{2} & \frac{1}{2} \\
\frac{1}{2} & \frac{1}{2}
\end{array}\right] \\
& =\left[\begin{array}{ll}
1 & 0 \\
0 & 3
\end{array}\right]
\end{aligned}
$$

Jika dicermati bentuk matriks diagonal $D$ merupakan matriks dengan entri diagonal utama merupakan nilai-nilai eigen dari matriks $A$.

Selain menggunakan multiplisitas geometri dan multiplisitas aljabar, untuk 
dapat menentukan suatu matriks persegi dapat didiagonalisasi atau tidak, dapat digunakan polinomial minimum. Misalkan $A$ adalah suatu matriks persegi dengan order berhingga atas suatu lapangan $\mathbb{F}$, dan $\mathbb{F}[x]$ melambangkan himpunan semua polinomial dari $A$, terdapat polinomial minimum dalam $\mathbb{F}[x]$ yang pengertiannya diberikan pada Definisi 19.

Definisi 19. Polinomial $f$ disebut polinomial minimum dari $A$ atas $\mathbb{F}$, yaitu apabila $f$ merupakan polinomial monik berderajat paling rendah di dalam $\mathbb{F}[x]$ yang memenuhi $f(A)=O$, dengan $O$ adalah matriks nol (Robinson, 2006).

Suatu matriks persegi $A$ atas lapangan $\mathbb{F}$ pasti mempunyai polinomial minimum. Lebih lanjut, keberadaan polinomial minimum tersebut adalah tunggal. Hal tersebut dibuktikan pada Teorema 20.

Teorema 20. Diberikan suatu matriks persegi $A$ dengan order berhingga atas suatu lapangan $\mathbb{F}$. Terdapat dengan tunggal $m_{A}(x) \in \mathbb{F}[x]$ yaitu polinomial monik berderajat paling rendah yang memenuhi $m_{A}(A)=O$. Dengan kata lain, $A$ mempunyai polinomial minimum tunggal (Fuhrmann, 2012).

Bukti. Pertama, akan dibuktikan eksistensi polinomial minimum dari matriks persegi dengan membuktikan adanya polinomial monik untuk matriks tersebut. Misalkan matriks $A$ berdimensi $n$ atas lapangan $\mathbb{F}$. Himpunan $\left\{I, A, \ldots, A^{n}\right\}$ adalah saling bergantungan linear sebab beberapa matriks dapat ditulis sebagai kombinasi linear dari matriks-matriks yang lain (misal $I+A=A$, dst). Sedemikian hingga untuk

$$
\sum_{i=0}^{n} \alpha_{i} A^{i}=0
$$

terdapat koefisien $\alpha_{i} \in \mathbb{F}$ yang tidak semuanya sama dengan nol dengan $i=0,1, \ldots, n$. Jika $\alpha_{k} \neq 0 \quad$ dan $\sum_{i=0}^{k} \alpha_{i} A^{i}$ adalah polinomial berderajat paling rendah dalam $\mathbb{F}[x]$ yang memenuhi $\quad \sum_{i=0}^{k} \alpha_{i} A^{i}=O \quad$ untuk $0<k \leq n$, maka dari persamaan berikut

$$
\alpha_{k} A^{k}+\sum_{i=0}^{k-1} \alpha_{i} A^{i}=0
$$

diperoleh

$$
A^{k}+\sum_{i=0}^{k-1} \frac{\alpha_{i}}{\alpha_{k}} A^{i}=0 .
$$

Sehingga didapatkan polinomial monik

$$
m_{A}(x)=x^{k}+\sum_{i=0}^{k-1} \frac{\alpha_{i}}{\alpha_{k}} x^{i}
$$

elemen $\mathbb{F}[x]$ yang merupakan polinomial minimum.

Selanjutnya, ditunjukkan ketunggalan polinomial minimum, yaitu misalkan $m_{A}(x)$ polinomial monik dengan derajat paling rendah $k$ dan $f(x) \in \mathbb{F}[x]$ adalah polinomial monik lain berderajat $k$ yang memenuhi $f(A)=O$. Akan ditunjukkan $m_{A}(x)=f(x), \quad$ untuk setiap $x \in \mathbb{F}$ sebagai berikut:

Misalkan terdapat suatu polinomial $q(x) \in \mathbb{F}[x]$ dengan $q(x)=m_{A}(x)-$ $f(x)$. Polinomial $m_{A}(x)$ dan $f(x)$ keduanya merupakan polinomial monik berderajat $k$, maka $q(x)$ adalah polinomial berderajat kurang dari $k$ dengan

$$
\begin{aligned}
q(A) & =m_{A}(A)-f(A) \\
& =O .
\end{aligned}
$$

Akan tetapi, menurut pernyataan yang diketahui, $k$ adalah derajat terendah untuk polinomial dalam $\mathbb{F}[x]$ yang memenuhi sama dengan $O$ saat disubstitusikan $A$, sehingga $q(A)=0$ jika dan hanya jika $q(x)=0$. Oleh karena itu, persamaan (1) menjadi 
dan diperoleh

$$
0=m_{A}(A)-f(A)
$$

$$
m_{A}(A)=f(A), \forall x \in \mathbb{F}
$$

Jadi terbukti $m_{A}(x) \in \mathbb{F}[x]$ adalah tunggal. Dengan kata lain, polinomial minimum dari matriks $A$ adalah tunggal.

Polinomial minimum suatu matriks membagi polinomial karakteristik dari matriks tersebut. Dengan kata lain, persamaan karakteristik merupakan kelipatan dari polinomial minimum suatu matriks.

Teorema 21. Diberikan matriks persegi $A$ dengan order berhingga atas lapangan $\mathbb{F}$. Suatu polinomial $f(x) \in \mathbb{F}[x]$ memenuhi $f(A)=O$ jika dan hanya jika $m_{A}(x) \mid f(x)$ (Fuhrmann, 2012).

Bukti. $(\Rightarrow)$ Polinomial $f(x)$ dengan Teorema 6 (Teorema Pembagian) dapat ditulis sebagai

$f(x)=m_{A}(x) q(x)+r(x) \quad \ldots(2)$ dengan $q(x), r(x) \in \mathbb{F}[x]$ dan $r(x)=0$ atau $\operatorname{deg} r(x)<\operatorname{deg} m_{A}(x)$. Substitusi $A$ pada persamaan (2) dan misal $f(A)=O \quad$ didapatkan $\quad r(A)=O$. Berdasarkan Teorema 20, $m_{A}(x)$ adalah polinomial minimum tunggal atau tidak ada lagi polinomial monik dengan derajat lebih rendah dari pada $m_{A}(x)$ yang memenuhi sama dengan $O$ saat disubtitusikan $A$ ke dalam polinomial tersebut. Oleh karena itu, untuk $r(A)=O$ jika dan hanya jika $r(x)=0$, dan persamaan (2) menjadi

$$
f(x)=m_{A}(x) q(x)
$$

Dengan kata lain, $m_{A}(x) \mid f(x)$.

$(\Leftarrow)$ Misalkan $m_{A}(x) \mid f(x)$, maka dapat ditulis $f(x)=m_{A}(x) g(x)$. Substitusi $A$ pada persamaan tersebut didapatkan $f(A)=O$.

Suatu matriks persegi dapat didiagonalisasi apabila polinomial minimumnya dapat difaktorkan menjadi faktor-faktor yang berbeda. Hal tersebut dibuktikan pada teorema berikut.

Teorema 22. Misalkan $A$ adalah matriks persegi dengan order berhingga atas lapangan $\mathbb{F}$. Matriks $A$ dapat didiagonalisasi jika dan hanya jika polinomial minimumnya dapat difaktorkan menjadi faktor-faktor yang berbeda (Fuhrmann, 2012).

Bukti. $(\Rightarrow)$ Jika matriks $A$ dapat didiagonalisasi, maka terdapat matriks invertible $P$ yang berlaku $P^{-1} A P=D$, sedemikian hingga matriks $A$ similar dengan matriks $D$. Misal $\lambda_{1}, \ldots, \lambda_{r}$ adalah entri diagonal yang berbeda-beda dari matriks $D$, maka nilai-nilai tersebut merupakan nilai eigen dari $D$. Diberikan polinomial $f(x)=\left(x-\lambda_{1}\right) \ldots(x-$ $\left.\lambda_{r}\right)$, substitusi matriks $D$ pada $x$ dalam polinomial $f(x)$ sama dengan substitusi $\lambda_{i}$ untuk $i=1, \ldots, r$ sebab $D$ adalah matriks diagonal. Hal tersebut menyebabkan setiap entri diagonal dari $f(D)$ sama dengan nol, sehingga diperoleh $f(D)=O$. Setiap nilai eigen dari matriks $D$ adalah akar dari polinomial minimumnya, sehingga tidak boleh ada faktor dari $f(x)$ yang dihilangkan. Karena $f(x)$ merupakan polinomial monik berderajat terendah yang memenuhi $f(D)=O$ dan memuat setiap nilai eigen dari matriks $D$ maka dapat disimpulkan

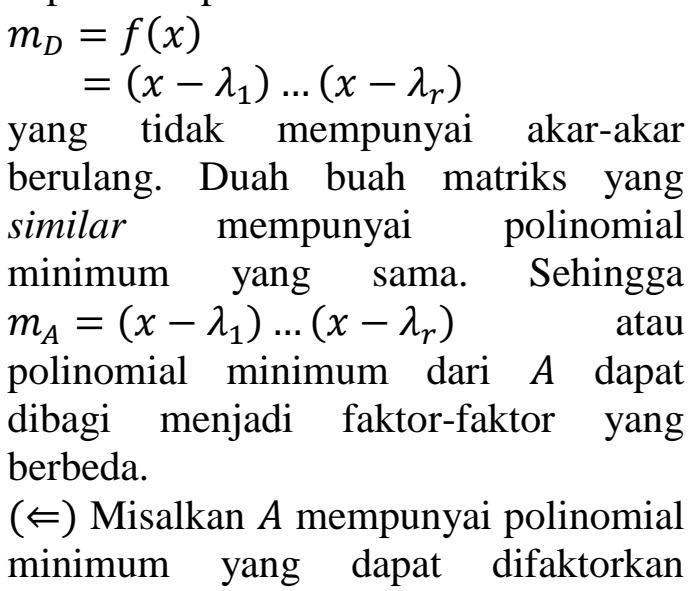


menjadi faktor-faktor yang berbeda, yaitu

$$
m_{A}=\left(x-\lambda_{1}\right) \ldots\left(x-\lambda_{r}\right)
$$

dengan $\lambda_{1}, \ldots, \lambda_{r}$ adalah nilai-nilai eigen dari $A$. Jelas matriks $A$ similar dengan matriks $D$ yaitu matriks yang entri diagonalnya sama dengan $\lambda_{1}, \ldots, \lambda_{r}$ yang juga merupakan nilai-nilai eigen dari matriks $D$. Jadi matriks $A$ dapat didiagonalisasi.

Berdasarkan uraian tersebut, dapat disusun suatu algoritma untuk menentukan suatu matriks persegi dapat didiagonalisasi atau tidak dengan menggunakan polinomial minimum. Lebih lanjut, jika suatu matriks persegi dapat didiagonalisasi, maka dapat disusun bentuk matriks diagonalnya.

\section{Algoritma 23. (Algoritma Polinomial Minimum)}

1. Ambil sebarang matriks persegi $A$ dengan order berhingga atas lapangan $\mathbb{F}$.

2. Dapatkan $\mathbb{F}[x]$ yang meliputi polinomial karakteristik $p(x)$ dan polinomial-polinomial lain yang membagi polinomial karakteristik.

3. Dapatkan semua $f(x) \in \mathbb{F}[x]$ yang memenuhi $f(A)=O$.

4. Tentukan polinomial minimum $m_{A}(x)$ dari langkah 3 .

5. Evaluasi $m_{A}(x)$ mempunyai faktorfaktor yang berbeda atau tidak.

a. Jika $m_{A}(x)$ mempunyai faktorfaktor yang berbeda, maka matriks $A$ dapat didiagonalisasi dan lakukan langkah 6.

b. Jika $m_{A}(x)$ mempunyai faktor kembar, maka dapat disimpulkan matriks $A$ tidak dapat didiagonalisasi, dan tahapan selesai.

6. Tentukan akar-akar dari polinomial karakteristik $p(x)$, misal $x_{1}, \ldots, x_{n}$.

7. Susun akar-akar dari polinomial karakteristik dalam entri diagonal utama dari matriks diagonal $D$, sehingga diperoleh matriks diagonal $D$ yang similar dengan matriks $A$ yaitu

$$
D=\left[\begin{array}{ccc}
x_{1} & \ldots & 0 \\
\vdots & \ddots & \vdots \\
0 & \ldots & x_{n}
\end{array}\right]
$$

dan tahapan selesai.

Untuk memperjelas penggunaan Algoritma 23 (Algoritma Polinomial Minimum), diberikan beberapa contoh.

Contoh 24. Diberikan matriks $A=$ $\left[\begin{array}{ll}2 & 1 \\ 1 & 2\end{array}\right]$ seperti pada Contoh 14,15 , dan 18. Berikut digunakan tahapan-tahapan Algoritma Polinomial Minimum untuk diagonalisasi matriks $A$ :

1. Matriks $A=\left[\begin{array}{ll}2 & 1 \\ 1 & 2\end{array}\right]$ merupakan matriks persegi berorder 2 atas lapangan real $\mathbb{R}$.

2. Didapatkan $\mathbb{R}[x]=\{1, x-1, x-$ $\left.3, p(x)=x^{2}-4 x+3\right\}$.

3. Elemen dari $\mathbb{R}[x]$ yang sama dengan $O$ apabila disubtitusikan $A$ adalah

$$
p(x)=x^{2}-4 x+3 .
$$

4. Polinomial minimum dari $A$ adalah $m_{A}(x)=p(x)=x^{2}-4 x+3$.

5. Polinomial minimum $m_{A}(x)=$ $(x-1)(x-3)$ mempunyai faktorfaktor yang berbeda sehingga dapat didiagonalisasi.

6. Menentukan akar-akar dari polinomial karakteristik $p(x)=$ $x^{2}-4 x+3$, yaitu $x_{1}=1$ dan $x_{2}=3$.

7. Akar-akar polinomial karakteristik disusun dalam entri diagonal $D$, diperoleh matriks diagonal yang similar dengan matriks $A$ adalah

$$
D=\left[\begin{array}{ll}
1 & 0 \\
0 & 3
\end{array}\right]
$$

Contoh 25. Berikut digunakan tahapantahapan Algoritma Polinomial Minimum untuk menentukan matriks 
persegi $\quad B=\left[\begin{array}{lll}4 & -2 & 2 \\ 6 & -3 & 4 \\ 3 & -2 & 3\end{array}\right] \quad$ dapat didiagonalisasi atau tidak. Lebih lanjut, jika matriks $B$ dapat didiagonalisasi, dapat ditentukan bentuk diagonal yang similar dengan matriks $B$.

1. Matriks $B$ merupakan matriks persegi berorder 3 atas lapangan real $\mathbb{R}$.

2. Didapat $\mathbb{R}[x]=\{1, x-1, x-$ 2, $x^{2}-2 x+1, x^{2}-3 x+$ 2, $\left.p(x)=x^{3}-4 x^{2}+5 x-2\right\}$.

3. Elemen-elemen dari $\mathbb{R}[x]$ yang sama dengan $O$ apabila disubtitusikan $B$ adalah

$$
\begin{gathered}
\left\{x^{2}-3 x+2, p(x)=x^{3}-4 x^{2}+\right. \\
5 x-2\}
\end{gathered}
$$

4. Polinomial minimum dari $B$ adalah $m_{B}(x)=x^{2}-3 x+2$.

5. Polinomial minimum $m_{B}(x)=$ $(x-1)(x-2)$ mempunyai faktorfaktor yang berbeda sehingga dapat didiagonalisasi.

6. Menentukan akar-akar dari polinomial karakteristik $p(x)=$ $x^{3}-4 x^{2}+5 x-2$, yaitu $x_{1}=1$, $x_{2}=1$, dan $x_{3}=2$.

7. Akar-akar polinomial karakteristik disusun dalam entri diagonal $D$, diperoleh matriks diagonal yang similar dengan matriks $B$ adalah

$$
D=\left[\begin{array}{lll}
1 & 0 & 0 \\
0 & 1 & 0 \\
0 & 0 & 2
\end{array}\right]
$$

Contoh 26. Diberikan matriks persegi $C=\left[\begin{array}{lll}3 & -2 & 2 \\ 4 & -4 & 6 \\ 2 & -3 & 5\end{array}\right]$. Untuk menentukan matriks $C$ dapat didiagonalisasi atau tidak digunakan tahapan Algoritma Polinomial Minimum.

1. Matriks $C$ merupakan matriks persegi berorder 3 atas lapangan real $\mathbb{R}$.
2. Didapat $\mathbb{R}[x]=\{1, x-1, x-$ $2, x^{2}-2 x+1, x^{2}-3 x+$ $\left.2, p(x)=x^{3}-4 x^{2}+5 x-2\right\}$.

3. Elemen dari $\mathbb{R}[x]$ yang sama dengan $O$ apabila disubtitusikan $C$ adalah

$$
p(x)=x^{3}-4 x^{2}+5 x-2
$$

4. Polinomial minimum dari $C$ adalah $m_{C}(x)=p(x)=x^{3}-4 x^{2}+5 x-$ 2.

5. Polinomial minimum $m_{C}(x)=$ $(x-1)^{2}(x-2)$ mempunyai faktor kembar sehingga tidak dapat didiagonalisasi.

\section{KESIMPULAN DAN SARAN}

Berdasarkan pembahasan diperoleh bahwa terdapat cara lain untuk menunjukkan secara tepat suatu matriks persegi dapat didiagonalisasi atau tidak, yang dilanjutkan dengan tahapan untuk menyusun bentuk matriks diagonal yang similar dengan matriks persegi yang diketahui tanpa menggunakan multiplisitas aljabar dan geometri. Cara lain tersebut mengadopsi dari sifat polinomial minimum dari suatu matriks persegi adalah tunggal dan membagi polinomial karakteristiknya, serta suatu matriks persegi dapat didiagonalisasi jika dan hanya jika polinomial minimumnya dapat difaktorkan menjadi faktor-faktor yang berbeda. Tahapan diagonalisasi suatu matriks persegi dengan menggunakan polinomial minimum selanjutnya dapat disebut sebagai Algoritma Polinomial Minimum.

\section{DAFTAR PUSTAKA}

Anton, H., \& Rorres, C. (2005). Elementary Linear Algebra with Applications, Ninth Edition: Application Version. New York: John Wiley \& Sons, Inc. 
ISSN 2089-8703 (Print) Vol. 6, No. 2 (2017)

ISSN 2442-5419 (Online)

Eves, H. (1968). Elementary Matrix Theory. Boston: Allyn and Bacon, Inc.

Fuhrmann, P. A. (2012). A Polynomial Approach to Linear Algebra, Second Edition. New York: Springer.

Koryanov, A. G. (2015). The Computer Program "Inverse Matrices". International Journal of Computer Discovered Mathematics (ICDM) , 0 (0), 4953.

Langi, Y. A. (2011). Penentuan Klasifikasi State pada Rantai Markov dengan Menggunakan Nilai Eigen dari Matriks Peluang Transisi. Jurnal Ilmiah Sains, 11 (1), 124-130.
Lipschutz, S., \& Lipson, M. (2009). Schaum's Outlines, Linear Algebra, Fourth Edition. New York: Mc Graw Hill.

Riyanto, M. Z. (2008). Retrieved Juli 10, 2017, from http://wahid.web.ugm.ac.id/dow nload/paper/Lapangan_Berhingg a_(Finite_Field).pdf

Robinson, D. J. (2006). A Course in Linear Algebra with Application, 2nd ed. Hackensack: World Scientific Publishing Co. Pte. Ltd.

Subiono. (2012). Aljabar Linier. Retrieved August 5, 2017, from Universitas Gunadarma Staff Site:

http://aris_gunaryati.staff.gunada rma.ac.id/Downloads 